\title{
ROZWIAZZANIA MATERIAŁOWO-KONSTRUKCYJNE W BUDYNKACH WYBRANYCH BROWARÓW RZEMIEŚLNICZYCH W POLSCE
}

\author{
Norbert Dąbkowski ${ }^{\circledR}$, Wojciech Chojecki \\ Wydział Budownictwa i Inżynierii Środowiska, Szkoła Główna Gospodarstwa Wiejskiego w Warszawie, Warszawa

\section{STRESZCZENIE}

\begin{abstract}
W artykule przedstawiono rozwiązania materiałowo-konstrukcyjne wybranych budynków browarów rzemieślniczych. Zbadano takie elementy, jak: fundamenty, ściany, wieńce i podciagi, dach, posadzki, instalacje. Dokonano analizy wykorzystania poszczególnych materiałów.
\end{abstract}

Słowa kluczowe: browar rzemieślniczy, budynek, rozwiązania materiałowo-konstrukcyjne

\section{WSTĘP}

W ostatnich latach, a w szczególności od 2011 roku, widoczny jest dynamiczny rozwój rynku piwa w Polsce. W całej produkcji piwnej, w pełni zdominowanej do tej pory przez koncerny piwowarskie, coraz większy udział mają powstające w znacznej liczbie browary rzemieślnicze. Zmiany te odzwierciedlają trendy światowe, obecne zwłaszcza w Stanach Zjednoczonych i Europie Zachodniej. Fenomen niewielkich browarów produkujących w małej skali polega $w$ głównej mierze na podniesieniu jakości oraz znacznym zwiększeniu różnorodności produktów, co przyjęło się na rynku niezwykle dobrze. Trwający obecnie okres powstawania kolejnych mikrobrowarów i docierania do coraz większej grupy odbiorców nazywany jest ,piwną rewolucją" (Carroll i Anand, 2000; Douglas i O'Neill, 2012; Wojtyra i Grudzień, 2017).

W Polsce nie istnieje jedna powszechnie uznana definicja browarów rzemieślniczych. Za najważniejszą cechę wyróżniającą browar jako rzemieślniczy (craftowy) uznaje się w środowisku znajomość piwowara. Ważne jest żeby człowiek znany z imienia i nazwiska mógł poświadczyć, że to on uwarzył konkretną partię piwa według własnej receptury. Drugą podstawową kwestią jest niezależność właścicielska. Browar taki nie może przynależeć do dużych koncernów alkoholowych (Podeszwa, 2015). Browary rzemieślnicze powinny warzyć za pomocą tradycyjnych $\operatorname{metod}^{1}$. Kolejną istotną sprawą jest ilość warzonego piwa. Ogólnie w odniesieniu do browarów rzemieślniczych mówi się o małej produkcji. W Polsce najczęściej jest to 20 tys. hektolitrów gotowego produktu rocznie (Wojtyra i Grudzień, 2017). Ostatnią kwestią, najważniejszą dla konsumentów, jest to że w browarach rzemieślniczych powstają najróżniejsze gatunki piw pszenicznych, ciemnych, kwaśnych, wędzonych oraz zawierających nietypowe dodatki wzbogacające smak i aromat. $\mathrm{W}$ procesie technologicznym produkcji piwa można wyróżnić następujące etapy: zacieranie, filtracja zacieru, gotowanie brzeczki, fermentacja, dojrzewanie piwa, filtracja i rozlew.

\footnotetext{
$\varpi_{\text {norbert_dabkowski@sggw.pl }}$

${ }^{1}$ Przez tradycyjne metody rozumie się, np. ręczne sterowanie aparaturą. 
W obliczu tak dynamicznego wzrostu postanowiono przyjrzeć się budynkom, w których mieszczą się omawiane browary.

\section{BADANIA BEZPOŚREDNIE}

Browary wizytowane były w 2016 i 2017 roku. W każdym z odwiedzonych browarów dokonano wizji lokalnej i przeprowadzono dokumentację fotograficzną w celu rozpoznania zastosowanych rozwiązań konstrukcyjnych, a także użytych materiałów budowlanych. Sprawdzono wszystkie elementy budynków od fundamentów, przez elementy nośne, po dachy i ich pokrycia. Informacje, których nie można było uzyskać na podstawie inwentaryzacji, to jest wiek budynku, jego historia i pierwotna funkcja w przypadku budynków adaptowanych na browar, pozyskano od pracowników obiektów. Ustalono również rodzaj przeprowadzonych remontów i modernizacji oraz ewentualnych planów rozbudowy.

Badaniom bezpośrednim poddanych zostało pięć browarów rzemieślniczych w Polsce. Wszystkie należą do kategorii mikrobrowarów (Wojtyra i Grudzień, 2017). Dwa spośród nich znajdują się w województwie mazowieckim, dwa w łódzkim i jeden w śląskim. Tylko jeden z odwiedzonych budynków był projektowany na browar od podstaw, pozostałe zostały adaptowane do tej funkcji.

Browar 1. Browar położony w Piotrkowie Trybunalskim został uruchomiony w 2014 roku i warzy piwo na większą skalę, by zaspokoić rosnący popyt. W okresie jednego roku powstał tam od podstaw budynek z warzelnią o wybiciu $20 \mathrm{hl}$ i leżakownią o łącznej pojemności $400 \mathrm{hl}$. Wyposażony jest on w nowoczesną linię rozlewniczą o wydajności do 2 tys. butelek na godzinę. Piwo rozlewane jest do butelek i kegów.

Browar składa się z trzech obiektów: budynku w konstrukcji tradycyjnej, murowanej z bloczków gazobetonowych (znajdują się tutaj pomieszczenia biurowe, socjalne, sanitariaty oraz magazyn gotowych produktów i komunikacja), budynku w konstrukcji szkieletowej żelbetowej z wypełnieniem ścian bloczkami (sekcja produkcyjna: warzelnia, fermentownia i leżakownia, syropiarnia, hala rozlewu, magazyny słodu, opakowań, chemii, surowców, laboratorium, rozdzielnia oraz komunikacja) oraz wolnostojącej hali stalowej typu lekkiego, przeznaczonej na magazyn pustych opakowań oraz gotowych napojów bezalkoholowych.

Budynek biurowy (rys. 1) wykonany jest w technologii murowanej tradycyjnej, $\mathrm{z}$ elementów drobnowymiarowych - bloczków gazobetonowych. Konstrukcja dachu - więźba drewniana z poszyciem z blachodachówki. Budynek produkcyjny (rys. 1 i 3 ) przylega do budynku biurowego, a oddzielony jest od niego dylatacja. Oba obiekty połączone są dwoma wewnętrznymi przejściami. Wykonany jest $\mathrm{w}$ technologii szkieletowej. Dźwigary dachowe, kratowe wykonane ze stali, oparte na słupach i wieńcach żelbetowych. Wypełnienie ścian zewnętrznych $\mathrm{z}$ bloczków $\mathrm{z}$ betonu komórkowego, poszycie dachu z płyt warstwowych. Budynek magazynowy (rys. 2 i 4) to wolnostojaca hala stalowa typu lekkiego wykonana $\mathrm{w}$ technologii ramowej. Konstrukcja słupów i dźwigarów wykonana $\mathrm{z}$ zamkniętych profili stalowych ocynkowanych ogniowo. Pokrycie ścian stanowią płyty warstwowe, natomiast dach przykryty jest plandeką z PCV.

Browar 2. Browar drugi jest położony we wsi Natolin, w powiecie grodziskim, w województwie mazowieckim. W 2015 roku zakupiono obecny budynek (poprzednio była tu hurtownia wędlin). Jest to niewielki browar rzemieślniczy o wybiciu $10 \mathrm{hl}$ i możliwościach produkcji do $120 \mathrm{hl}$ piwa miesięcznie. Browar mieści się w budynku o konstrukcji tradycyjnej, murowanej z bloczków gazobetonowych (rys. 5-7). Budynek jest dwukondygnacyjny, z poddaszem użytkowym, w obecnej chwili niezagospodarowanym. Cała produkcja mieści się na parterze, a piętro jest przygotowywane na otwarcie dodatkowej sekcji fermentowni i leżakowni w celu zwiększenia możliwości produkcyjnych. Na parterze znajdują się pomieszczenia: warzelnia, fermentownia i leżakownia, magazyn surowców, biuro i pomieszczenie sanitarne. Gotowe produkty są składowane częściowo w pomieszczeniu fermentowi i leżakowni, a częściowo w przybudówkach $\mathrm{w}$ postaci wiat $\mathrm{z}$ płyt warstwowych oraz płyt OSB i blachy trapezowej powlekanej (rys. 6). Browar nie posiada sekcji butelkowania, całość produkcji rozlewana jest do kegów ze stali nierdzewnej oraz petainerów. 


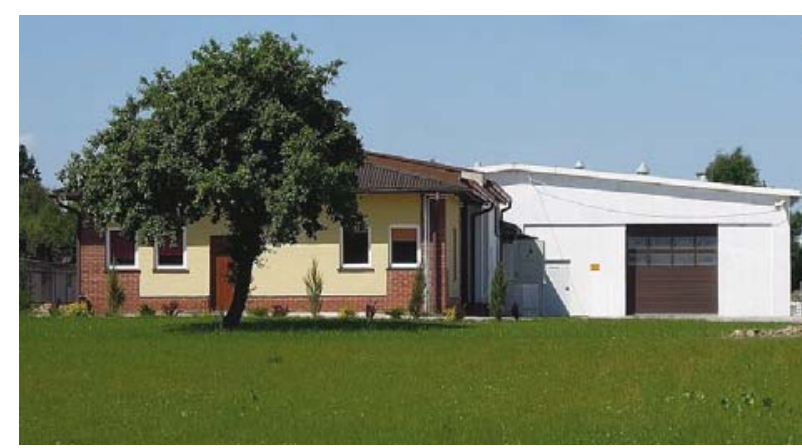

Rys. 1. Browar 1 widok od frontu - widoczny budynek biurowy i produkcyjny (fot. W. Chojecki)

Fig. 1. Brewery 1, front view - office and production building can be seen (photo by W. Chojecki)

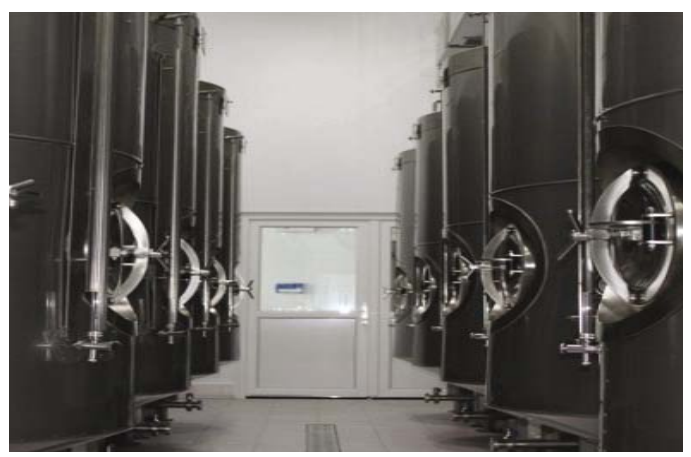

Rys. 3. Hala produkcyjna - wnętrze (fot. W. Chojecki) Fig. 3. Production hall - inside (photo by W. Chojecki)

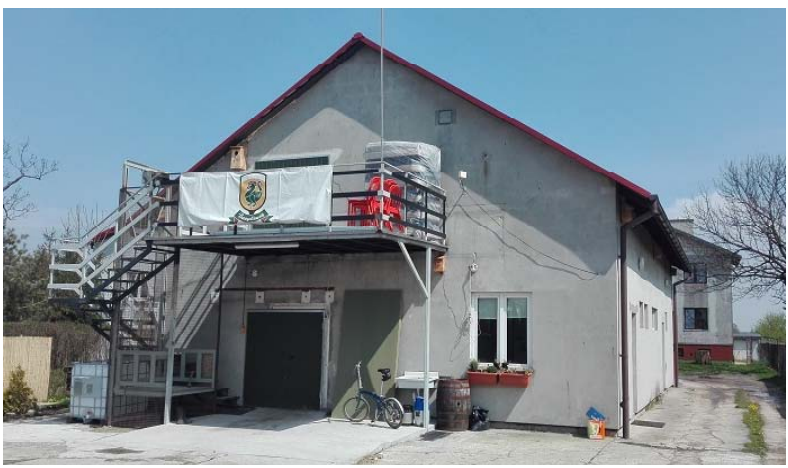

Rys. 5. Browar 2 - widok od frontu (fot. W. Chojecki) Fig. 5. Brewery 2 - front view (photo by W. Chojecki)

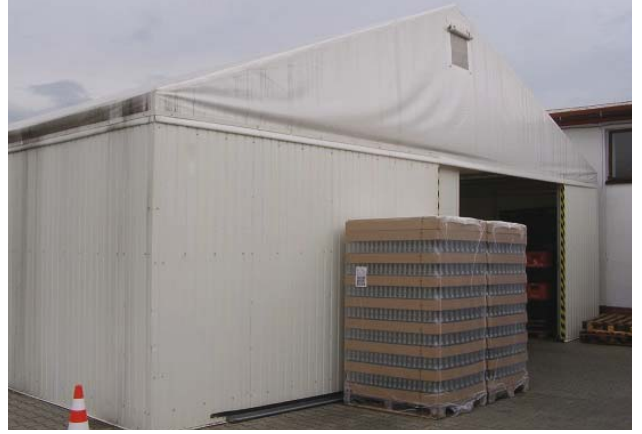

Rys. 2. Hala magazynowa (fot. W. Chojecki)

Fig. 2. Warehouse (photo by W. Chojecki)

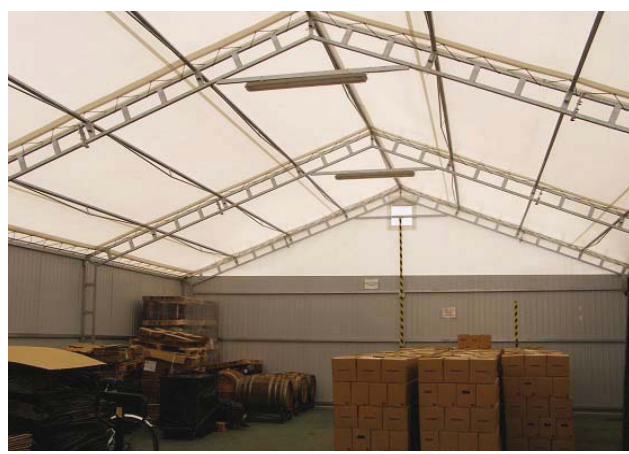

Rys. 4. Hala magazynowa - wnętrze (fot. W. Chojecki) Fig. 4. Warehouse - inside (photo by W. Chojecki)

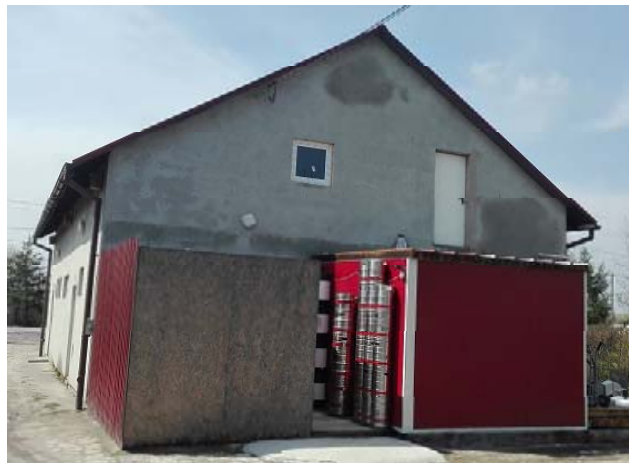

Rys.6. Widok od tyłu - widoczne wiaty niezwiązane trwale z gruntem (fot. W. Chojecki)

Fig. 6. Back view - sheds can be seen, not permanently connected to the ground (photo by W. Chojecki)
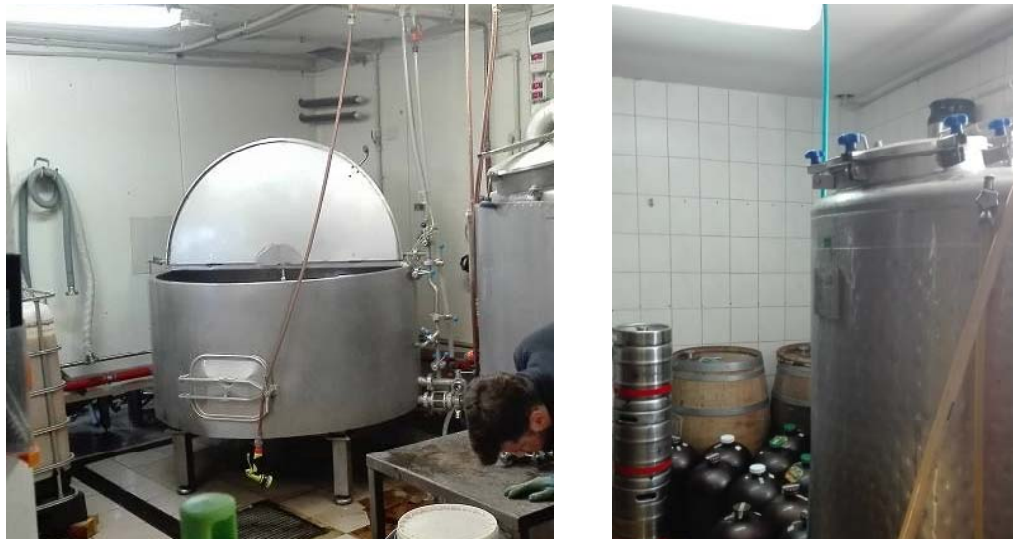

Rys. 7. Hala produkcyjna - wnętrze (fot. W. Chojecki)

Fig. 7. Production hall - inside (photo by W. Chojecki) 
Browar 3. Browar trzeci położony jest w Świętochłowicach, w województwie śląskim. Piwo jest tu warzone od lipca 2014 roku. Na wyposażeniu sekcji produkcyjnej znajduje się kocioł zacierno-warzelny o wybiciu $20 \mathrm{hl}$ i dość duża, jak na browary rzemieślnicze, leżakownia, składająca się z szesnastu zbiorników fermentacyjno-leżakowych o pojemności $40 \mathrm{hl}$ i czternastu o pojemności $20 \mathrm{hl}$, co daje łącznie $920 \mathrm{hl}$ objętości piwa, które może fermentować w jednym czasie. Kompleks składa się z trzech obiektów: budynku produkcyjnego, osobnego magazynu i kontenera biurowego.

Budynek produkcyjny (rys. 8) powstał w latach dwudziestych ubiegłego stulecia i należał wtedy do kompleksu kopalni węgla kamiennego „Śląsk”. Z relacji właścicieli był on prawdopodobnie magazynem węgla dla działającej w tamtych czasach niewielkiej elektrowni. Zanim został przekształcony w browar był wykorzystywany na magazyn ziemniaków. Znajdują się tu następujące pomieszczenia: warzelnia, dwie fermentownie i leżakownie, rozlewnia, myjnia kegów, magazyn surowców, pomieszczenie gospodarcze, szatnia z WC i pomieszczenie socjalne. Budynek został wymurowany z cegły ceramicznej. Jedna część, do której prowadzą wrota, powstała w formie tunelowej - ściany łukowe. Druga część ma ściany proste. W późniejszych latach ściany łukowe wzmocniono od wewnątrz stalowymi żebrami przykręconymi do muru (rys. 9). Budynek od zewnątrz ocieplono wełną mineralną i stworzono zabudowę z blachy trapezowej.

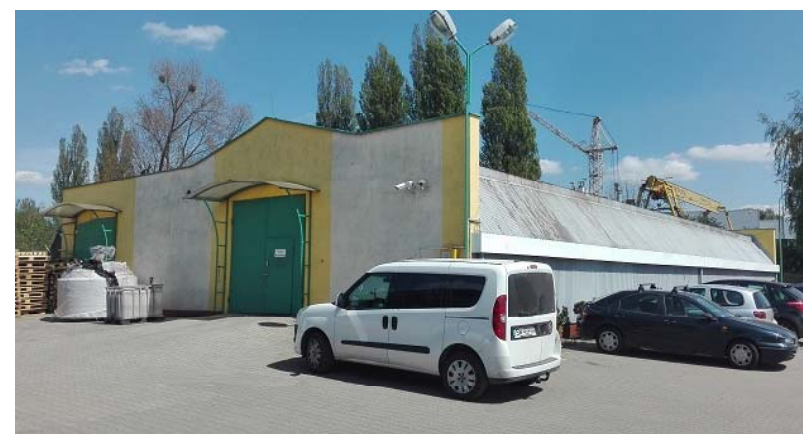

Rys. 8. Browar 3 - widok od frontu (fot. W. Chojecki) Fig. 8. Brewery 3, front view (photo by W. Chojecki)
Ściany szczytowe wystają ponad płaszczyznę dachu w formie attyk. Przez całą długość tej części obiektu, w której ściany są łukowe, stworzono doświetlenie w formie świetlików dachowych (rys. 10). Widoczna za świetlikami kratownica stalowa (rys. 10) biegnie przez całą długość budynku i kończy się w ścianach szczytowych. Na rysunku 11 przedstawiono jeden ze wsporników stalowych podtrzymujących stalowe żebra wzmacniające ściany. W drugiej części budynku, gdzie ściany są proste, konstrukcja dachu wykonana jest $\mathrm{z}$ dźwigarów wykonanych $\mathrm{z}$ rur kwadratowych stalowych (fragment widoczny na rys. 12).

Magazyn (rys. 13) mieści się w wolnostojącej hali namiotowej typu lekkiego gdzie składowane sa gotowe produkty zapakowane do transportu, a także puste opakowania, etykiety, sprzęt zapasowy itp. Jest wykorzystywany częściowo na inną działalność. Wykonany w technologii ramowej, konstrukcja słupów i dźwigarów wykonana z zamkniętych profili stalowych ocynkowanych ogniowo. Pokrycie dachu oraz ścian frontowych stanowi plandeka z PCV, ściany tylne oraz wydzielające poszczególne sekcje magazynu wykonano $\mathrm{z}$ blachy trapezowej na stelażu z profili stalowych.

Biuro (rys. 14) znajduje się w budynku powstałym $\mathrm{z}$ dwóch kontenerów biurowych wykonanych w konstrukcji stalowej z profili zimnogiętych zabezpieczonych farbami epoksydowymi. Dach i ściany wykonane są z płyty warstwowej o grubości $15 \mathrm{~cm}$. Podłoga izolowana wełną mineralną. Drzwi wejściowe są przeszklone w witrynie z oknami z PCV. W środku oprócz

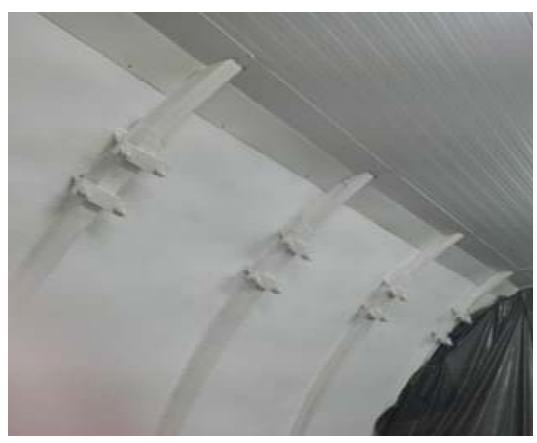

Rys. 9. Hala produkcyjna - ściana łukowa murowana z cegły i wzmocniona żebrami stalowymi (fot. W. Chojecki)

Fig. 9. Production hall - arc-shaped brick wall, reinforced by steel ribs (photo by W. Chojecki) 


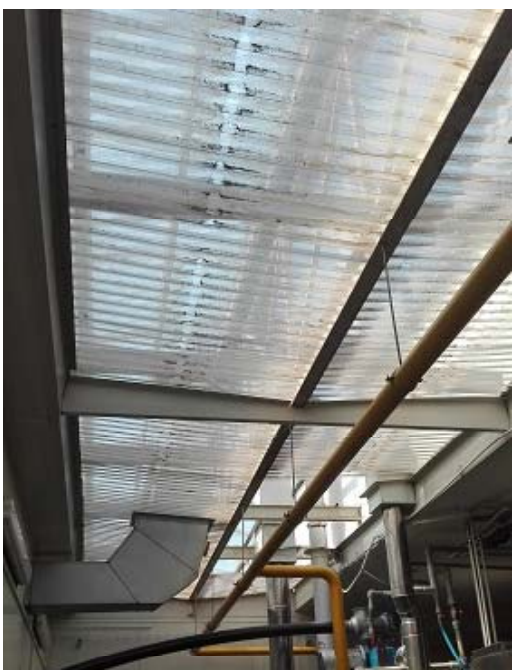

Rys. 10. Świetliki (fot. W. Chojecki)

Fig. 10. Skylights (photo by W. Chojecki)

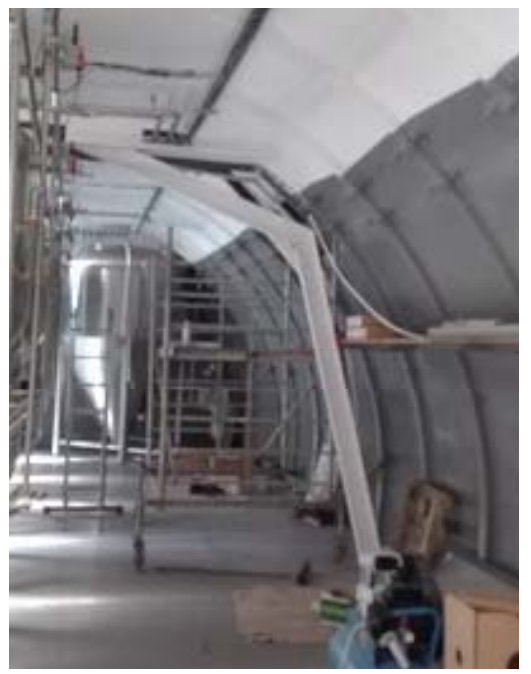

Rys. 11. Stalowy wspornik (fot. W. Chojecki

Fig. 11. Steel cantilever (photo by W. Chojecki)

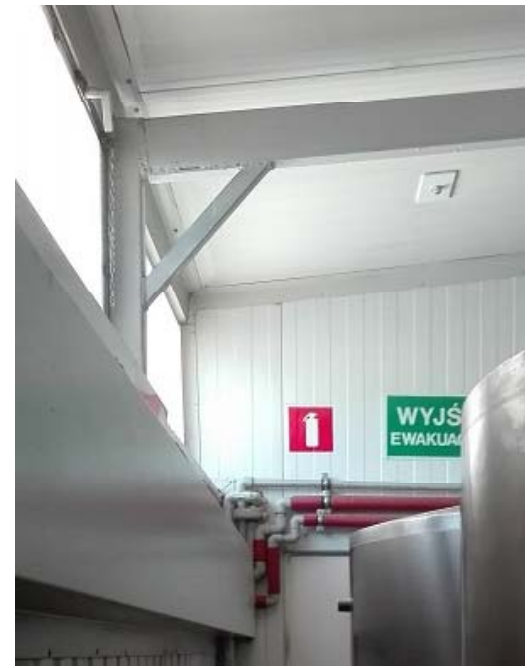

Rys. 12. Dźwigar dachowy (fot. W. Chojecki)

Fig. 12. Roof girder (photo by W. Chojecki)

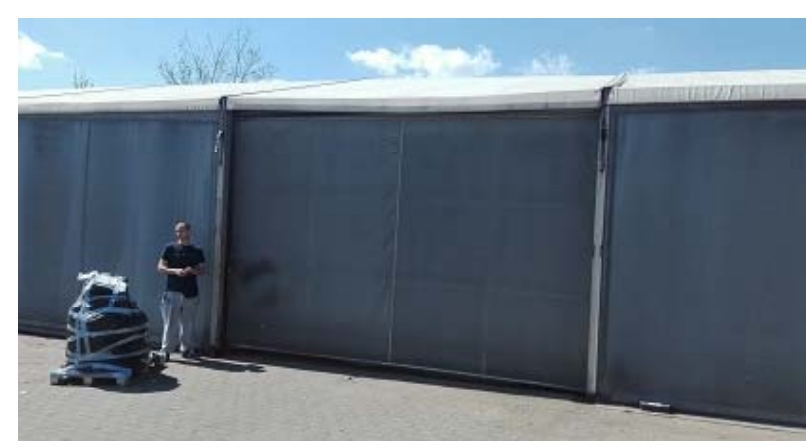

Rys. 13. Hala magazynowa (fot. W. Chojecki)

Fig. 13. Warehouse (photo by W. Chojecki)

przestrzeni biurowej znajduje się pomieszczenie sanitarne $\mathrm{i}$ aneks kuchenny.

Browar 4. Hala produkcyjna znajduje się w Błoniu, $\mathrm{w}$ powiecie warszawskim zachodnim. Pierwsze warki w nowym budynku uwarzone zostały w marcu 2015 roku. W obecnym wyposażeniu znajduje się kocioł zacierno-warzelny o wybiciu $30 \mathrm{hl}$ i leżakownia składająca się z pięciu tankofermentorów o łącznej pojemności $240 \mathrm{hl}$.

Budynek powstał w latach dwudziestych XX wieku i należał do kompleksu zakładów Mera-Błonie.

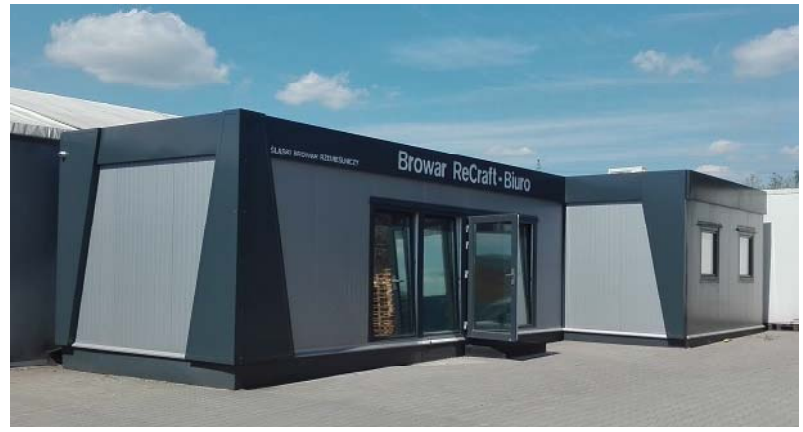

Rys. 14. Budynek biurowy (fot. W. Chojecki)

Fig. 14. Office building (photo by W. Chojecki)

W okresie przedwojennym produkowano tam zapałki, w latach pięćdziesiątych zegarki, w późniejszym okresie sprzęt wojskowy i komputerowy. W hali, w której znajduje się obecny browar, znajdowała się kompresorownia. Fundamenty projektowane pod ówczesne kompresory służą teraz za podporę kadzi zaciernej i tankofermentorów. Widoczna na rysunku 15 hala jest jednokondygnacyjna, za nią znajduje się część socjalna (poszerzenie), która jest podpiwniczona. Technologia wykonania konstrukcji w części socjalnej - tradycyjna, murowana $z$ cegły wapienno-piaskowej, na hali konstrukcja szkieletowo- 


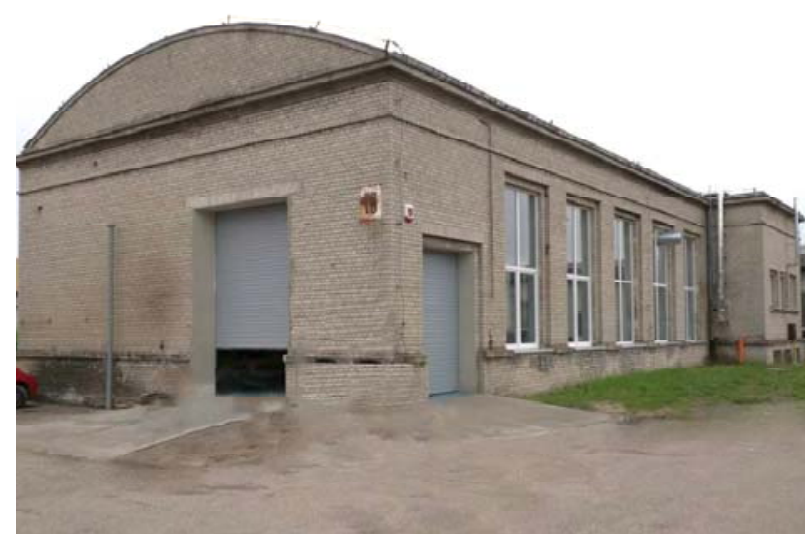

Rys. 15. Browar 4 - widok od frontu (fot. W. Chojecki)

Fig. 15. Brewery 4 - front view (photo by W. Chojecki)

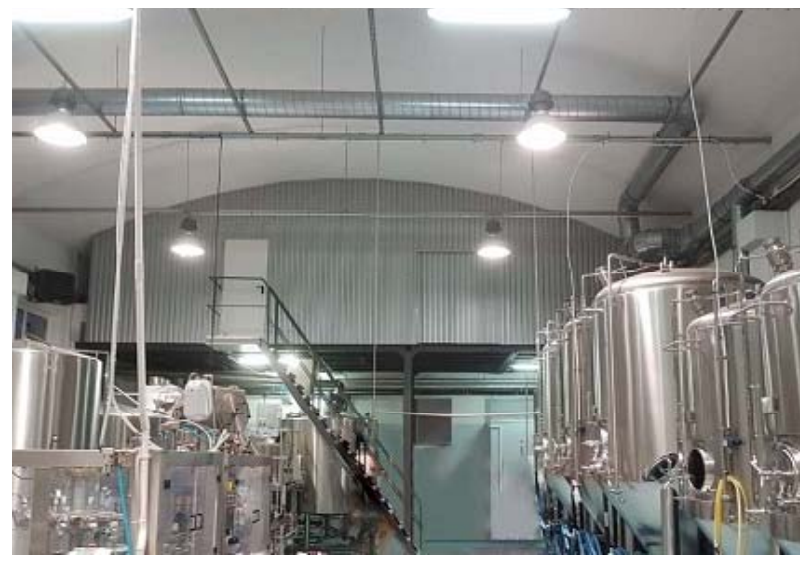

Rys. 16. Wnętrze budynku - widoczna antresola z pomieszczeniem śrutowni i magazynu słodu (fot. W. Chojecki)

Fig. 16. Building inside - mezzanine with gristing room and malt store (photo by W. Chojecki)

Browar 5. Ostatni browar jest położony w Łodzi. -murowa - słupy żelbetowe i cegła wapienno-piaskowa. Hala produkcyjna stanowi jedną przestrzeń, z której wydzielono jedynie niedużą chłodnię zbudowaną z płyt warstwowych oraz pomieszczenie na dobudowanej antresoli w konstrukcji stalowej, gdzie mieści się magazyn słodu i śrutownia. Pomieszczenie to obudowane jest blachą trapezową na lekkim stalowym stelażu (rys. 16). Dach hali wykonany został w konstrukcji powłokowej, łupinowej. Jest to lekka, cienkościenna konstrukcja $\mathrm{z}$ betonu zbrojonego siatką prętów o średnicy 6 lub $8 \mathrm{~mm}$. Technologia ta stosowana jest przeważnie do wykonywania przekryć o dużej rozpiętości i bardzo małej grubości. Konstrukcje takie powstają z dwukrzywiznowych elementów, będących w przybliżeniu wycinkiem powierzchni paraboloidy hiperbolicznej. Stosuje się je zwykle w obiektach specjalnego przeznaczenia, gdzie oprócz wymaganej dużej rozpiętości 15-24 m dąży się do stworzenia układu konstrukcyjnego bez wewnętrznych podpór. Zaczęto je stosować na początku XX wieku (Ajdukiewicz i Mames, 2004). Grubość omawianej powłoki wynosi prawdopodobnie około $8 \mathrm{~cm}$. Widoczne pod sklepieniem stalowe pasy, do których zamontowano oświetlenie, pełnią funkcję ściągów konstrukcyjnych. Są one rozmieszczone w takim samym rozstawie co słupy żelbetowe.
Znajduje się w kompleksie połączonych budynków o całkowitej powierzchni zabudowy prawie $1400 \mathrm{~m}^{2}$, sąsiaduje $\mathrm{z}$ dużą piekarnią. Browar posiada warzelnię o wybiciu $15 \mathrm{hl}$ oraz fermentownię i leżakownię, w której znajdują się aktualnie trzy tanki leżakowe, o pojemności 30 hl każdy. Budynek jest na tyle rozległy, że możliwe będzie kilkukrotne powiększenie produkcji. Pierwsze piwo zaprezentowano w 2015 roku.

Kompleks budynków, zdaniem właścicieli, ma około 40 lat. Składa się z pięciu oddylatowanych od siebie, ale połączonych wspólnymi przejściami obiektów. Centralna hala powstała w konstrukcji szkieletowej, na słupach żelbetowych z wypełnieniem pustakami ceramicznymi, wszystkie pozostałe budynki wzniesiono w konstrukcji tradycyjnej murowej z pustaków ceramicznych. Jeden z obiektów jest dwukondygnacyjny - parter $z$ poddaszem użytkowym. Pozostałe są parterowe, niepodpiwniczone.

Do browaru przynależą dwa budynki (rys. 17). W budynku w kształcie litery L (widocznym na pierwszym planie) znajdują się pomieszczenia socjalne, biurowe i magazynowe. Budynek na drugim planie to hala, gdzie zlokalizowano produkcję. Znajdziemy tam warzelnię, fermentownię i leżakownię (rys. 18), śrutownik oraz rozlewnię. 


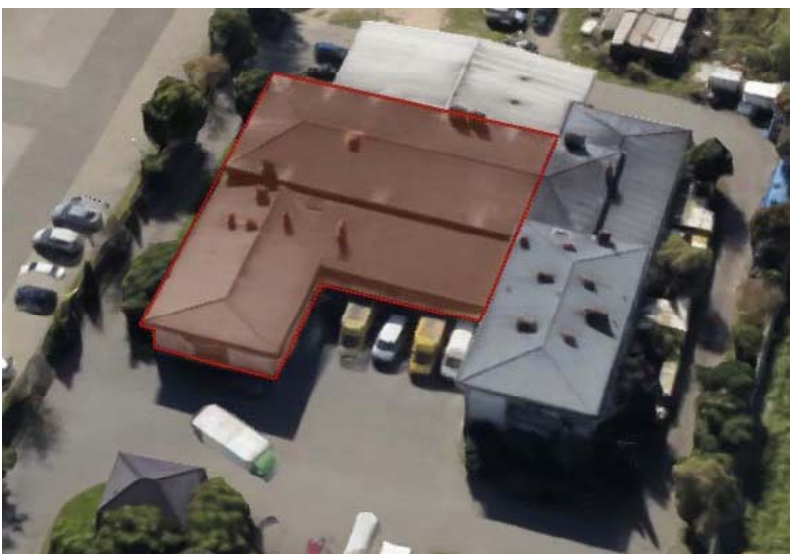

Rys. 17. Browar 5 - widok z lotu ptaka (oprac. własne na podstawie Google maps)

Fig. 17. Brewery 5 - bird's-eye view (Based on the Google maps)

\section{ANALIZA MATERIAtU Z BADAŃ BEZPOŚREDNICH}

Budynki browarów rzemieślniczych mają zazwyczaj po kilkadziesiąt lat. $\mathrm{Z}$ analizy wieku opisywanych tutaj obiektów wynika, że większość powstała w ubiegłym stuleciu (rys. 19). Jeżeli ich stan techniczny nie budzi zastrzeżeń i nie stanowi zagrożenia, to można z powodzeniem wykorzystać obiekty, które mają prawie sto lat, jak to miało miejsce w browarach 3 i 4 . W ich przypadku szczególnie ważne będą okresowe przeglądy i kontrole stanu technicznego, zwłaszcza po montażu wszelkich urządzeń i instalacji.

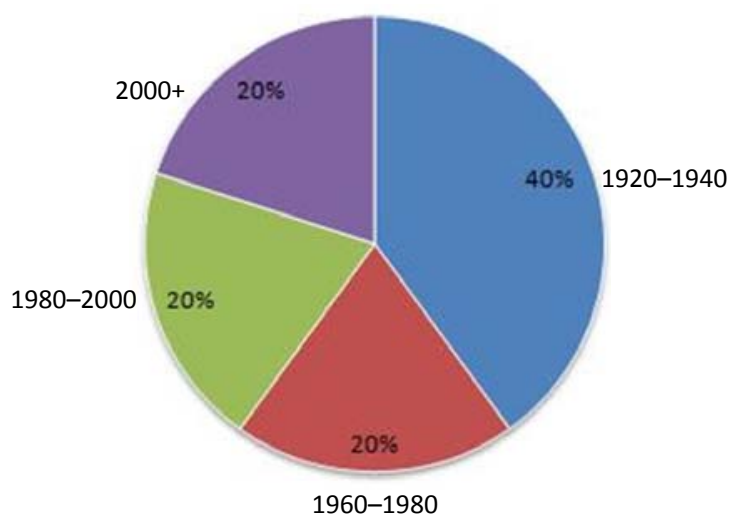

Rys. 19. Lata budowy budynków

Fig. 19. Years of construction buildings

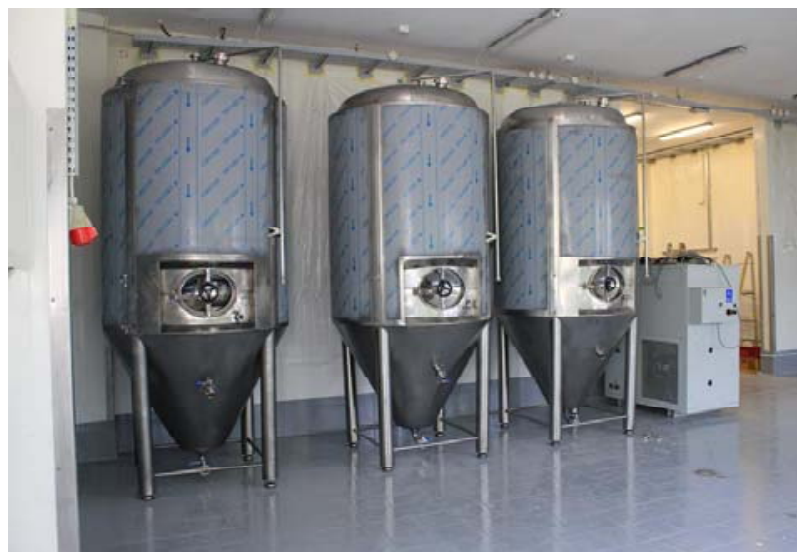

Rys. 18. Fermentownia i leżakownia (fot. W. Chojecki)

Fig. 18. Fermentation room and lagering cellar (photo by W. Chojecki)

Fundamenty wszystkich obiektów wykonano $\mathrm{z}$ betonu zbrojonego. $\mathrm{W}$ miejscach, gdzie przewidziano zbiorniki: kotty zacierno-warzelne i tankofermentory, utworzono dodatkowe fundamenty blokowe, również z żelbetu.

Do wznoszenia ścian zastosowano pełną gamę materiałów budowlanych, od ceramiki, przez silikaty i bloczki z betonu komórkowego, po płyty warstwowe (rys. 20). Ściany w starszych budynkach murowano głównie z cegły ceramicznej lub cementowo-wapiennej. W obiektach bliższych naszym czasom powszechniej stosowano pustaki ceramiczne lub bloczki z betonu komórkowego. Piwowarzy dysponujący

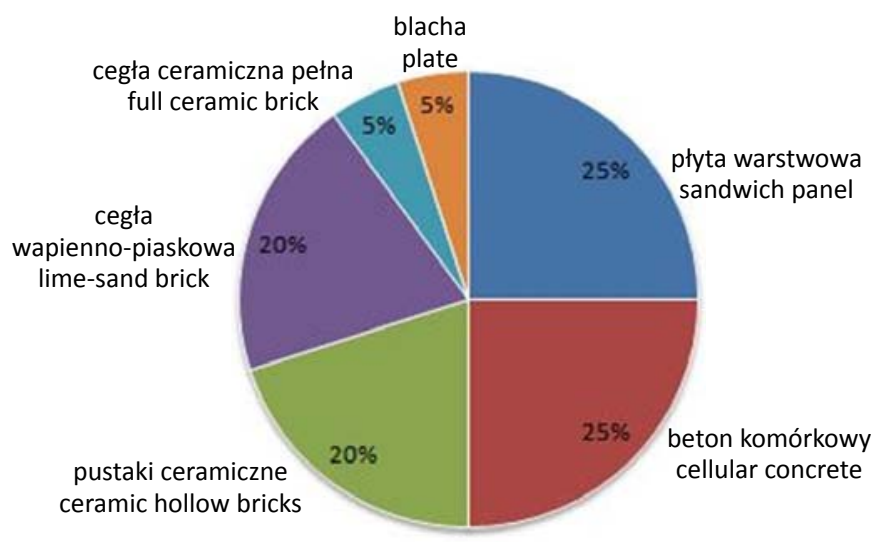

Rys. 20. Materiały użyte do budowy ścian

Fig. 20. Materials used to build walls 
dodatkową przestrzenią na działce często stawiają tam zewnętrzne, nieogrzewane magazyny. Powstają one w konstrukcji lekkich hal namiotowych. Obudowę zewnętrzną takich magazynów wykonuje się $\mathrm{z}$ blachy trapezowej lub plandeki PCV. Obecnie bardzo dużą popularnością cieszą się płyty warstwowe. Są one stosowane na przegrody niespełniające funkcji nośnej, tj. ściany działowe lub obudowę zewnętrzną na konstrukcji szkieletowej. Zapewniaja one dobra izolację termiczną, są szybkie i „,czyste” w montażu, a ponadto gwarantują łatwo zmywalną powierzchnię bez dodatkowego wykończenia. Na rysunku 20 przedstawiono materiały ścienne użyte w odwiedzonych browarach, w ujęciu procentowym.

Zdecydowana większość budynków browarów jest parterowa i stropy w nich nie występuja. Jedynie w czesściach socjalnych i biurowych zdarzają się obiekty dwukondygnacyjne. Stropy w tych obiektach wykonano jako płyty $\mathrm{z}$ betonu zbrojonego.

Do wykonania konstrukcji dachowych najczęściej wykorzystywano stal, z uwagi na duże rozpiętości pomieszczeń produkcyjnych (rys. 21). Budynki o mniejszych rozpiętościach $\mathrm{w}$ większości przypadków kryte są więźbą drewnianą. Mały ciężar, atrakcyjna cena i łatwość obróbki to cechy, które maja największy wpływ na jej zastosowanie. $\mathrm{W}$ browarze 4 do konstrukcji dachowych wykorzystano beton zbrojony. Dach nad halą produkcyjną wykonano w konstrukcji powłokowej, łupinowej, a nad częścią socjalną - z płyty.

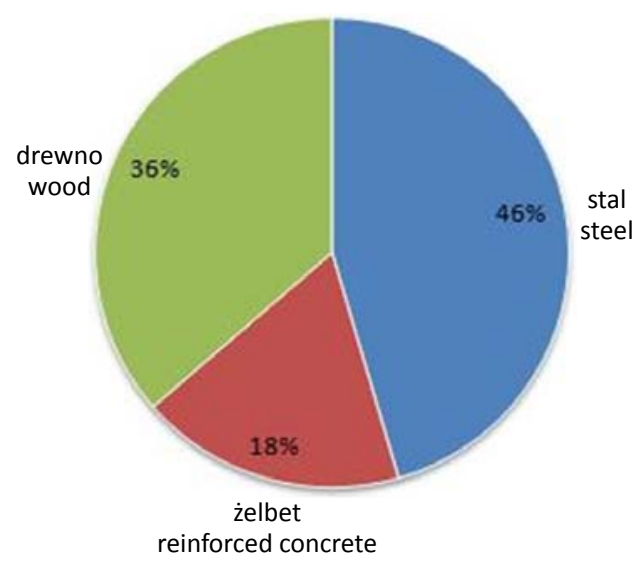

Rys. 21. Materiały użyte na konstrukcje dachowe Fig. 21. Materials used for roof constructions
Przodującym materiałem stosowanym do pokryć dachów w zbadanych budynkach była papa (rys. 22). Głównym czynnikiem przemawiającym za wyborem tego rozwiązania jest cena. Pokrycia bitumiczne można wykonać stosunkowo niewielkim kosztem, a dodatkową zaletą jest lekkość konstrukcji. Papę stosuje się jednak tylko przy dachach o niewielkim nachyleniu lub na dachach płaskich. Ma to związek z mocnym nagrzewaniem się materiału pod wpływem promieniowania słonecznego - tak rozgrzana papa może spływać z dachów o dużym spadku. Innym stosowanym materiałem jest blacha. Wykorzystana w postaci blachodachówki, która zapewnia lekkość konstrukcji, jest droższa, ale można ją zastosować przy większych pochyleniach połaci. Magazyny powstałe w technologii lekkich hal namiotowych posiadały poszycie z plandek PCV. Sa one wygodne w stosowaniu, ponieważ nie stwarzaja problemów, jeżeli wystapi potrzeba powiększenia czy pomniejszenia magazynu. Tworzywo to jest niepalne, a jego trwałość sięga kilkunastu lat. Przepuszczalność światła pozwala na oszczędzenie energii elektrycznej w ciagu dnia.

Budynek biurowy browaru 3 wykonany został w całości z płyt warstwowych. Powstał on $\mathrm{z}$ dwóch kontenerów systemowych, przygotowanych wcześniej w wytwórni i dowiezionych na miejsce. Jest to coraz częściej spotykane rozwiązanie. Zarówno dach, jak i ściany takich konstrukcji kryte są płytami, które zapewniają dobrą izolacyjność cieplną, estetyczny wygląd oraz szybkość montażu.

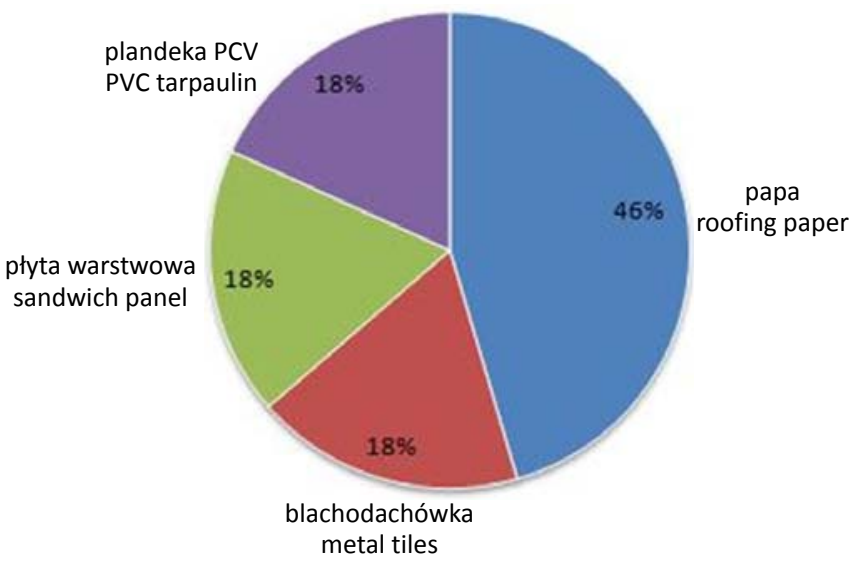

Rys. 22. Materiały użyte na pokrycia dachowe

Fig. 22. Materials used for roof coverings 


\section{PODSUMOWANIE}

Browary rzemieślnicze powstają głównie na terenach o przeznaczeniu przemysłowym, z niezbyt gęstą zabudowa. Związane jest to $\mathrm{z}$ koniecznością uzyskania zgody (czy raczej braku sprzeciwu) na działalność od ewentualnych sąsiadów. Lokal musi posiadać w posadzce wszystkich pomieszczeń produkcyjnych odprowadzenie ścieków technologicznych w postaci kratek ściekowych punktowych lub liniowych. Najlepiej jest, gdy cała produkcja, a przynajmniej warzelnia, zlokalizowana jest w pomieszczeniach o wysokości w świetle przynajmniej 3,30 m. Kanalizacje bytowa i technologiczna powinny być rozdzielone. Bardzo ważna jest infrastruktura techniczna. Przyłącze wody powinno mieć odpowiednią średnicę przepływu, gdyż zwykła sieć daje zbyt małe ciśnienie. Sieć elektryczna musi mieć 5-10 kW lub więcej, gdy kocioł będzie grzany elektrycznie. Sieć gazowa jest wskazana, chociaż palnik kotła można też zasilać z butli. Koniecznością jest przyłącze kanalizacyjne, gdyż ilość ścieków będzie duża. Minibrowar jest inwestycją mogącą oddziaływać na środowisko, wymaga zatem uzyskania decyzji środowiskowej. Ze względu na produkcję żywności musi spełniać przepisy Państwowej Inspekcji Sanitarnej pod względem wymagań higienicznych i zdrowotnych. Pozostałe wymagania określają odpowiednie przepisy budowlane. Kwestią bardzo ważną w cyklu produkcji piwa jest izolacja termiczna pomieszczeń fermentowni i leżakowni. Większość piw powinna leżakować w temperaturze kilku stopni powyżej zera, więc aby ograniczyć koszty schładzania, pomieszczenia powinny być ocieplone.

Obiekty objęte badaniami, zgodnie ze specyfiką browarów rzemieślniczych, okazały się w większości małe. Powierzchnia użytkowa w najmniejszym z nich - browarze 2, tylko nieznacznie przekracza $100 \mathrm{~m}^{2}$. Największe - browary 1 i 3, z powierzchnią zabudowy zbliżoną do dziesięciu arów, nadal nie mogą się równać $\mathrm{z}$ browarami przemysłowymi. Przekłada się to również na liczbę pracowników: w minibrowarach pracuje od kilku do kilkunastu osób. Najmniejsze z browarów nie posiadają sekcji butelkowania, nawet ręcznego, dzięki czemu nie potrzebują dodatkowego pomieszczenia.

$\mathrm{Z}$ analizy wynika, że zdecydowana większość warzelni jest adaptowana na swoją funkcję z budynków o innym przeznaczeniu. Stąd też wykorzystywane w nich materiały budowlane, a także układ funkcjonalny bardzo się między sobą różnią. Budynki wykorzystywane na potrzeby mikrobrowarów różnią się znacznie od budynków browarów w miastach tworzonych na przełomie wieków (np. Kulpa, 2016). Osobną kategorię stanowiły kiedyś budynki browarów zlokalizowanych przy majątkach ziemskich (Gubańska, 2009).

W kwestii materiałów użytych do zastanych rozwiązań budynków browarów występuje duża różnorodność, zarówno browary zbudowane w konstrukcji murowej, jak i szkieletowej czy halowej spełniają swoją funkcję. Nie ma większego znaczenia, czy ściany powstały z cegiel, bloczków, czy płyt warstwowych, pod warunkiem, że wykończone przegrody zapewniają odpowiednią izolacyjność termiczną.

Budynki zbadanych browarów są tylko obiektami produkcyjnymi i nie stanowią spójnej względem formy architektonicznej koncepcji. Odmiennie niż tzw. browary restauracyjne (np. Uniejów, Sopot, Gliwice, Zielona Góra), które wykorzystują wyeksponowany częściowo ciąg technologiczny produkcji piwa do podniesienia atrakcyjności miejsca.

\section{PIŚMIENNNICTWO}

Ajdukiewicz, A. i Mames, J. (2004). Konstrukcje z betonu sprężonego. Kraków: Polski Cement.

Carroll, G. i Anand, S. (2000). Why the microbrewery movement? Organizational dynamics of resource partitioning in the US brewing industry. The American Journal of Sociology, 106 (3), 715-762.

Douglas, W. M. i O’Neill, M. A. (2012). Craft beer: penetrating a niche market. British Food Journal, 114 (7), 899-909.

Gubańska, R. (2009). Budynki i budowle dolnośląskich folwarków. Wrocław: Uniwersytet Przyrodniczy we Wrocławiu, Monografie LXXXVII.

Kulpa, S. (2016). Historia warzona piwem. Rzecz o browarach Wodzisławia Ślaskiego. Wodzisław Śląski.

Podeszwa, T. (2015). Browarnictwo rzemieślnicze (craft-brewing) - oddolna aktywność mikrowytwórców stymulantem rozwoju rynku i samokształcenia w zakresie browarnictwa. Acta Innovations, 15, 61-56.

Wojtyra, B. i Grudzień, Ł. (2017). Rozwój przemysłu piwowarskiego w Polsce w okresie tzw. piwnej rewolucji w latach 2011-2016. Prace Geografii Przemystu Polskiego Towarzystwa Geograficznego, 31 (1), 52-67. 


\section{MATERIAL AND CONSTRUCTIONAL SOLUTION BUILDINGS SELECTED CRAFT} BREWERIES IN POLAND

\section{ABSTRACT}

The work presents material and construction solutions for selected buildings craft breweries. Elements such as foundations, walls, rims and beams, ceilings, floors, installations were examined. The analysis of the use of individual materials was made.

Key words: craft brewery, building, material and construction solutions 